\title{
Radar stratigraphy of the glaciotectonically deformed deposits in the Isoniemi area, Haukipudas, Finland
}

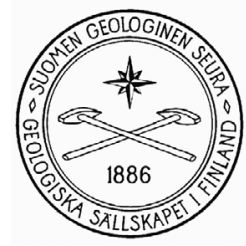

\author{
Antti Pasanen \\ Department of Geosciences, P.O. Box 3000, FI-90014 University of Oulu, Finland
}

\begin{abstract}
The study of deposits in the central areas of Weichselian Scandinavian Ice Sheet (SIS) is important for understanding behaviour of the ice sheet. This study provides new information on the deposits in the previously poorly known glaciofluvial Isoniemi complex in Haukipudas, Finland, located in the central part of SIS. The deposits are studied using ground penetrating radar (GPR) to delineate the depositional and glaciotectonic environments and events that have occurred in the area. The results are interpreted using the principles of radar stratigraphy and correlated with an earlier sedimentological study from the area. Borehole logs of old boreholes made for ground water and aggregate investigations are used as an aid in the interpretation alongside the previously obtained sedimentological data. GPR data show 10 radar facies separated by seven radar surfaces. The sequence of events interpreted from GPR data and earlier sedimentological study include: I) deposition of the glaciofluvial sediments, 2) deposition of till and the first stage of deformation by an advancing glacier, 3) retreat of the glacier, and cutting and infilling of the proglacial channels, 4) proglacial deformation forming the Runteli ridge, 5) glacioisostatic uplift close to the water level, 6) possible forming of the rip current channels and 7) reworking of the earlier sediments by wave and sea-ice action.
\end{abstract}

Key words: glaciofluvial features, sediments, till, stratigraphy, ground-penetrating radar, glaciotectonics, deformation, Quaternary, Isoniemi, Haukipudas, Finland

* Corresponding author email: antti.pasanen@oulu.fı

\section{Introduction}

The Oulu region (Fig. 1) was covered by the Weichselian Scandinavian Ice Sheet (SIS) when it advanced across Finland to the Northwest Russia several times during the Late Pleistocene. The region, located in the middle part of the SIS, is considered important in understanding the behaviour of the SIS during the Weichselian Stage. The till stratigraphical investigations suggest that three till beds were deposited by three separate ice advances in Finnish Lap- land and the area north of Oulu during the Weichselian Stage, ca. 116000 - 11500 years ago (Hirvas, 1991). Lapland was covered by ice during the Early Weichselian, the early Middle Weichselian and during the Late Weichselian (Hirvas, 1991; Lunkka et al., 2004; Johansson \& Kujansuu, 2005; Helmens et al., 2007). The stratigraphical investigations south of the Pudasjärvi-Hossa line (Fig. 1), however, suggest that the SIS advanced into central and Southern Fin- 


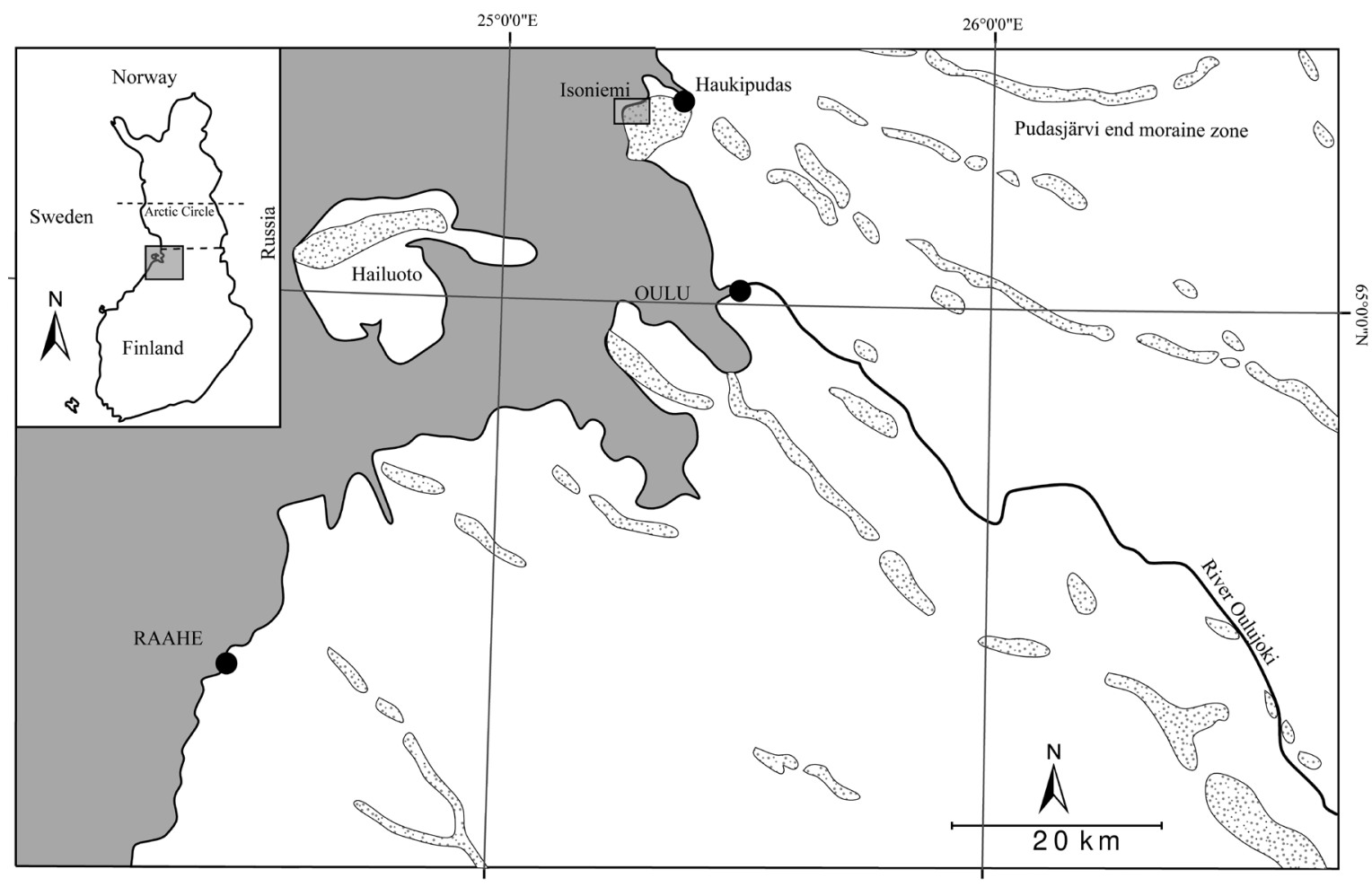

Fig. I. Map of Oulu region showing the major glaciofluvial deposits (dotted areas). The shaded box in Isoniemi shows the area covered in Figure 2. Pudasjärvi End Moraine Zone and Pudasjärvi-Hossa line (lower dashed line in small map) are indicated.

land only during the early Middle Weichselian and the Late Weichselian (Lunkka et al., 2004; Salonen et al., 2007). It has been hypothesised that the series of till-covered glaciofluvial ridges in the Pudasjärvi endmoraine zone (Fig. 1), represent the Early Weichselian ice limit deposited by a glacier flowing from the northwest (Sutinen, 1992; Nenonen, 1995). It has also been suggested that a number of till-covered glaciofluvial complexes in the Oulu region were deposited prior to the Late Weichselian Sub-stage (Bargel et al., 1999; Johansson \& Kujansuu, 2005).

The Isoniemi area $\left(\mathrm{N} 65^{\circ} 09^{\prime} \mathrm{E} 25^{\circ} 15^{\prime}\right)$ discussed here consists of a glaciofluvial sediment sequence overlain by till. The lower part of the sequence has been intensively deformed by the overriding ice. During the deformation, the area was covered by water. The highest shoreline north of Oulu in the Rovaniemi area is currently $220 \mathrm{~m}$ asl, and it was formed in the Baltic Sea's Anculys Stage (Tikkanen
\& Oksanen, 2002). This suggests that during the deglaciation, the water depth in the Isoniemi area was more than $200 \mathrm{~m}$. The deep water also caused a rise in pore water pressure which lowered the sediments ability to withstand the deformation. Glacioisostatic uplift started right after the deglaciation in the early Holocene lifting the area from the Baltic Sea. The upper part of the sequence has been reworked by the wave and sea ice action (Pasanen \& Lunkka, 2008). Borehole data from the Runteli ridge (Fig. 2) shows a sedimentary sequence, almost 90 m thick, consisting of glacial and glaciofluvial sediments above the Muhos Formation sedimentary bedrock (K. Mäkinen, pers. comm. 2005). Glacial striation measurements taken from the bedrock exposures in the Oulu region indicate two separate ice flow phases, the first from the northwest and the latter movement from the west (Hirvas \& Nenonen, 1987; Bargel et al., 1999). However, ages of these ice flow events and 


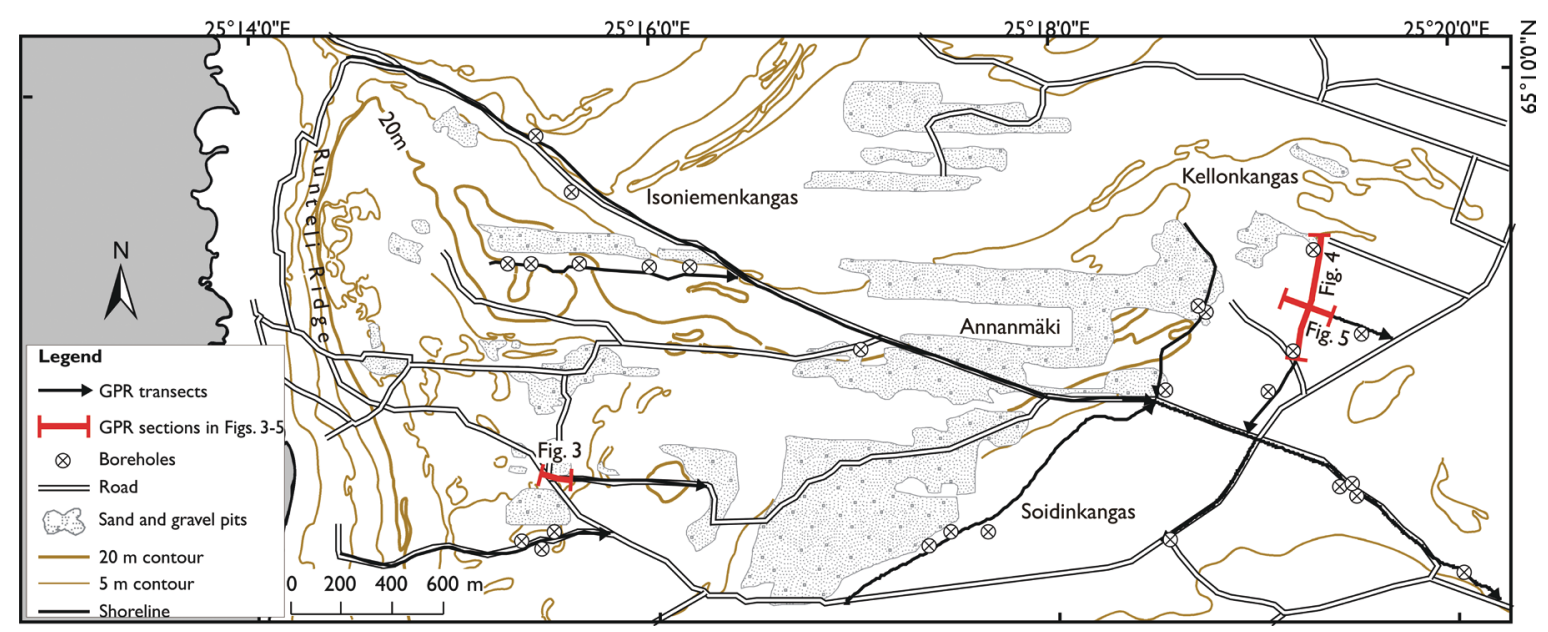

Fig. 2. Map of the Isoniemi study area showing the locations of GPR transects and selected boreholes used to aid in the radar stratigraphy interpretation.

the glaciofluvial sediments beneath the till unit are not known.

Despite the intensive exploitation of sand and gravel, which have left behind numerous sediment exposures, only two scientific studies have been performed in the Isoniemi area (Vehkaperä, 1988; Pasanen \& Lunkka, 2008). Vehkaperä (1988) studied the Quaternary sediments and the underlying bedrock in the Haukipudas-Kiiminki area, including the Isoniemi area, in his unpublished licentiate study. Vehkaperä (1988) interpreted the Runteli ridge (Fig. 2), which runs north-south along the western side of Isoniemi, as an ice marginal deposit. Vehkaperä (1988) also noted that on the distal side of the Isoniemi area, at least three kilometres from the Runteli ridge, lenses and layers of till at several different depths below the ground surface occur separated by thick units of glaciofluvial sediment. This is thought to have been caused by intensive deformation of the sediments. Pasanen \& Lunkka (2008) studied sections in currently exploited sand and gravel pits in the Isoniemi area using sedimentological techniques including clast fabric and structural measurements. They described four distinct sedimentary facies (from the bottom to the top): 1) deformed sand and gravel facies, which was interpret- ed to represent glaciotectonically deformed fan-delta sediments; 2) diamicton facies, interpreted to represent deformation till consisting of reworked glaciofluvial sediment and glacially transported sediment; 3) cobble gravel facies, which laterally grades into diamicton and is interpreted to represent littoral reworking of the deformation till and 4) sand and pebble gravel facies interpreted to represent littoral reworking of the earlier sediments. The structural measurements showed two distinct shear stress directions, one from the northwest and the other from the west or the southwest, but a clear time relationship between the events could not be determined in the Isoniemi area. Other work from the Oulu region has noted the littoral deposits and till-covered glaciofluvial areas of Hangaskangas and Muhos with a sequence similar to the one in Isoniemi (Helle \& Ylinen, 1965; Gibbard, 1979; Eronen et al., 1995; Bargel et al., 1999; Pasanen \& Lunkka, 2008).

In this paper, the Isoniemi area was studied using ground penetrating radar (GPR) which is the most prominent high resolution geophysical profiling method for coarse grained sediments. The aim of the paper is to establish the radar stratigraphy, correlate it with the lithostratigraphy presented in $\mathrm{Pa}$ sanen \& Lunkka (2008), show the lateral variability 
of the sedimentary facies interpreted from the radar stratigraphy and shed light on the sedimentary environments in the Isoniemi area.

\section{Study area}

The Isoniemi area $\left(\mathrm{N} 65^{\circ} 09^{\prime} \mathrm{E} 25^{\circ} 15^{\prime}\right.$, Fig. 2) is the northern part of the $25 \mathrm{~km}^{2}$ glaciofluvial IsoniemiVirpiniemi complex. It is located on the coast of the Gulf of Bothnia $6 \mathrm{~km}$ northwest of the village of Kello in the Haukipudas Commune. The highest geomorphological feature in the area is the Runteli ridge which reaches over 25 metres above sea level ( $\mathrm{m}$ asl). The modern ground surface surrounding the Runteli ridge is at $20-25 \mathrm{~m}$ asl, descending to $10 \mathrm{~m}$ asl towards the east. Vast sand and gravel pits dominate the area. Outside the pits, the area is mainly forested.

\section{Methods}

The area was studied using 2D GPR sections (location of the sections in Fig. 2). GPR is a powerful, non-intrusive electromagnetic profiling technique for revealing sedimentary structures in a shallow subsurface. Using this method, pulses of electromagnetic energy are transmitted into the subsurface where the energy is reflected back from the electrical boundaries, and the amplitude and the two-way travel time in nanoseconds are recorded. The electrical boundaries are created at the interfaces of the geological materials with different dielectrical properties. The velocity of the electromagnetic wave is dependant on the relative dielectric value $\left(\varepsilon_{\mathrm{r}}\right)$, and the abrupt changes in $\varepsilon_{\mathrm{r}}$ cause the radar reflections. In sediments, the abrupt changes in $\varepsilon_{\mathrm{r}}$ are mainly caused by changes in water content and lithology (van Dam \& Schlager, 2000). The physical basis for the GPR method is given by Annan \& Davis (1976) and Daniels et al. (1988) among others.

The propagation and reflection of the electromagnetic wave is analogous to an acoustic wave, therefore, an approach similar to seismic stratigraphy (Roksandic, 1978; Sangree \& Widmier, 1979) can be used for GPR interpretation. Radar stratigraphy is based on the recognition and interpretation of radar surfaces (bounding surfaces), radar facies (bed assemblages) and radar packages (geometry of the deposits) (Neal et al., 2002). The principles of radar stratigraphy are given by Gawthorpe et al. (1993) and later reviewed by Neal (2004).

The GPR method has been widely used in sedimentological studies (cf. Neal, 2004) and has been successfully applied to glaciofluvial sediments, e.g. by Beres et al. (1995, 1999) and Mäkinen \& Räsänen (2003), and to deltaic and glaciodeltaic sediments, e.g. by Jol \& Smith (1991), Smith \& Jol (1992, 1997), Roberts et al. (2003) and Pelpola \& Hickin (2004). In recently glaciated terrain, the radar reflections of glaciotectonic structures can provide invaluable information concerning ice-sheet dynamics. Glaciotectonic structures have been studied using GPR by Lønne \& Lauritsen (1996), Busby \& Merritt (1999), Overgaard \& Jakobsen (2001), Jakobsen $\&$ Overgaard (2002), Bakker \& Van der Meer (2003) and Bakker (2004) among others.

GPR investigation comprises 10 GPR sections with a total length of 12290 metres. The GPR equipment used in this study comprised of the Malå Geoscience $100 \mathrm{MHz}$ shielded antenna and the Malå Geoscience X3M controller unit. Raw data were postprocessed using GeoDoctor v.2.054 software, and the processing and survey parameters are given in Table 1. The average relative dielectricity value $\left(\varepsilon_{\mathrm{r}}\right)$, used for the depth conversion, was estimated by fitting the diffraction hyperbolae and using borehole logs, made for ground water and aggregate investigations. In GPR sections where diffraction hyperbolae and borehole logs could not be applied, $\varepsilon_{\mathrm{r}}$ was estimated from the literature (Davis \& Annan, 1989; Hänninen, 1991; Neal, 2004). The topography of the radar transects was obtained from map altitude contours and enhanced with the calibrated altimeter.

\section{Results}

The results are given in Table 2, where ten radar facies (RF) and seven radar surfaces (RS) are presented with the geological interpretation of their genesis. In ad- 
Table I. Collection and post-processing parameters of the GPR survey. The average step size is calculated from the survey time and transect distance.

\begin{tabular}{|c|c|c|c|c|}
\hline & Transect & Isoniemi 2 & Isoniemi 8 & Isoniemi 7 \\
\hline \multicolumn{5}{|c|}{ data collection parameters } \\
\hline & Figure & Fig. 3 & Fig. 4 & Fig. 5 \\
\hline & Location & $\begin{array}{c}\text { Isoniemenkangas, Haukipu- } \\
\text { das, Finland }\end{array}$ & $\begin{array}{c}\text { Kellonkangas, Haukipudas, } \\
\text { Finland }\end{array}$ & $\begin{array}{c}\text { Kellonkangas, Haukipudas, } \\
\text { Finland }\end{array}$ \\
\hline & GPR Unit & $\begin{array}{c}\text { Malå Geoscience, Ram- } \\
\text { ac X3M }\end{array}$ & $\begin{array}{c}\text { Malå Geoscience, Ram- } \\
\text { ac X3M }\end{array}$ & $\begin{array}{c}\text { Malå Geoscience, Ram- } \\
\text { ac X3M }\end{array}$ \\
\hline & Data logging & $\begin{array}{c}\text { Panasonic Toughbook } \\
\text { CF-29 with Malå Geo- } \\
\text { science GroundVision soft- } \\
\text { ware. } \\
\end{array}$ & $\begin{array}{c}\text { Panasonic Toughbook } \\
\text { CF-29 with Malå Geo- } \\
\text { science GroundVision soft- } \\
\text { ware. } \\
\end{array}$ & $\begin{array}{c}\text { Panasonic Toughbook } \\
\text { CF-29 with Malå Geo- } \\
\text { science GroundVision soft- } \\
\text { ware. }\end{array}$ \\
\hline & Survey type & Common offset & Common offset & Common offset \\
\hline & $\begin{array}{c}\text { Antenna centre frequency } \\
(\mathrm{MHz})\end{array}$ & 100 & 100 & 100 \\
\hline & Antenna Separation $(\mathrm{m})$ & 1 & 1 & 1 \\
\hline & Mode of data collection & $\begin{array}{l}\text { Continuous, time trigger, } \\
\text { radar was towed by a car. }\end{array}$ & $\begin{array}{l}\text { Continuous, time trigger, } \\
\text { radar was towed by a car. }\end{array}$ & $\begin{array}{l}\text { Continuous, time trigger, } \\
\text { radar was towed by a car. }\end{array}$ \\
\hline & Stacking & 2 & 2 & 2 \\
\hline & Time window & $531 \mathrm{~ns}$ & $629 \mathrm{~ns}$ & $566 \mathrm{~ns}$ \\
\hline & Average step size & $16.5 \mathrm{~cm}$ & $23.2 \mathrm{~cm}$ & $19.6 \mathrm{~cm}$ \\
\hline \multicolumn{5}{|c|}{ post-processing steps } \\
\hline 1 & Data editing & $\mathrm{x}$ & $\mathrm{x}$ & $\mathrm{x}$ \\
\hline 2 & $\begin{array}{l}\text { Relative dielectricity value } \\
\text { for depth conversion }\end{array}$ & $\begin{array}{c}4(0.15 \mathrm{~m} / \mathrm{ns}) \text {. Taken from } \\
\text { literature and borehole logs } \\
\text { in other profiles }\end{array}$ & $\begin{array}{c}14(0.08 \mathrm{~m} / \mathrm{ns}) \text {. Taken from } \\
\text { hyperbola fitting. }\end{array}$ & $\begin{array}{c}14(0.08 \mathrm{~m} / \mathrm{ns}) . \text { Taken from } \\
\text { hyperbola fitting. }\end{array}$ \\
\hline 3 & Topography correction & $\begin{array}{c}\text { Contours, altimetre, } \\
\text { markers }\end{array}$ & $\begin{array}{c}\text { Contours, altimetre, } \\
\text { markers }\end{array}$ & $\begin{array}{c}\text { Contours, altimetre, } \\
\text { markers }\end{array}$ \\
\hline 4 & Set time-zero & $\mathrm{x}$ & $\mathrm{x}$ & $\mathrm{x}$ \\
\hline 5 & $\begin{array}{l}\text { Amplitude zero-level cor- } \\
\text { rection }\end{array}$ & $\mathrm{x}$ & $\mathrm{x}$ & $\mathrm{x}$ \\
\hline 6 & Background removal (scans) & 400 & 400 & 400 \\
\hline 7 & $\begin{array}{c}\begin{array}{c}\text { Vertical low-pass boxcar fil- } \\
\text { ter }(\mathrm{MHz})\end{array} \\
\end{array}$ & 454.5 & 381.5 & 381.5 \\
\hline 8 & $\begin{array}{c}\text { Vertical high-pass boxcar fil- } \\
\text { ter (MHz) }\end{array}$ & 39.5 & 40.2 & 40.2 \\
\hline \multirow[t]{4}{*}{9} & Automatic gain control & & & \\
\hline & - calculation windows & 12 & 12 & 12 \\
\hline & - mean amplitude & 3000 & 3000 & 3000 \\
\hline & - window overlap $\%$ & 50 & 50 & 50 \\
\hline
\end{tabular}

dition, separate radar reflections interpreted to represent structures of post-depositional deformation are showed as secondary elements (SE1). The radar surfaces and radar facies are numbered consecutively from the bottom to the top in the order they are presented in the example figures (Figs. 3-5) and their interpretations are discussed briefly below. 
Table 2. Results of the radar stratigraphy interpretation and geological interpretation for each radar facies and radar surface. RF refers to radar facies, RS to radar surface and SE to secondary element in radar element column. The interpretations are discussed in the text.

\begin{tabular}{l|l|l}
\hline $\begin{array}{l}\text { Radar } \\
\text { element }\end{array}$ & Description & Geological interpretation \\
\hline Figure 3 & \multicolumn{2}{|l}{} \\
\hline RF1 & $\begin{array}{l}\text { Complex series of wavy and subparallel, discontinuous to moderately } \\
\text { continuous reflections. The radar facies is erosionally truncated by radar } \\
\text { surface RS1 and the present ground surface }\end{array}$ & $\begin{array}{l}\text { Glaciotectonically deformed glaciofluvi- } \\
\text { al deposit. }\end{array}$ \\
\hline SE1 & $\begin{array}{l}\text { Planar to mildly wavy reflections crosscutting the original strata. The ap- } \\
\text { parent dip of the reflections is 15-270 towards the west }\end{array}$ & Glaciotectonic thrust faults \\
\hline RS1 & Wavy reflection with a complex topography. & Erosional, probably a wave-cut, surface \\
\hline RF2 & $\begin{array}{l}\text { Low amplitude, wavy, moderately continuous reflections with mainly } \\
\text { downlapping lower boundary to RS1 }\end{array}$ & Littorally reworked sediments \\
\hline
\end{tabular}

Figure 4

\begin{tabular}{|c|c|c|}
\hline RF3 & $\begin{array}{l}\text { Wavy, subparallel and discontinuous to moderately continuous reflec- } \\
\text { tions with increasing noise towards the bottom. The upper boundary is } \\
\text { erosionally truncated by RS3 and probably deformed to RS2. }\end{array}$ & $\begin{array}{l}\text { Glacial diamicton ie. till. The nature of } \\
\text { the till is probably glaciotectonic }\end{array}$ \\
\hline$\overline{\mathrm{RS} 2}$ & $\begin{array}{l}\text { Wavy reflection with a complex topography which is very difficult to de- } \\
\text { termine }\end{array}$ & Possible deformational boundary \\
\hline$\overline{\mathrm{RF} 4}$ & $\begin{array}{l}\text { Complex series of wavy, horizontal and dipping reflections which are } \\
\text { partly masked by shadow reflections from the ground water surface at } \\
\text { the top of the radar facies. The radar facies is erosionally truncated by } \\
\text { RS3, RS4 and RS5 at the upper boundary and partly downlapping and } \\
\text { deformational to RS2 at the lower boundary }\end{array}$ & $\begin{array}{l}\text { Probably glaciotectonically deformed } \\
\text { glaciofluvial deposit. }\end{array}$ \\
\hline RS3 & Concave, continuous reflection & Erosional bottom of a proglacial channel \\
\hline$\overline{\text { RF5 }}$ & $\begin{array}{l}\text { Concave, parallel to subparallel, continuous reflections with a concord- } \\
\text { ant and partly downlapping lower boundary to RS3 and concordant and } \\
\text { partly erosional upper boundary to RS4 }\end{array}$ & Proglacial channel fill deposits \\
\hline$\overline{\mathrm{RS} 4}$ & $\begin{array}{l}\text { Concave, continuous reflection with a steeper dip angle at the northern } \\
\text { part of the radar surface }\end{array}$ & $\begin{array}{l}\text { Erosional bottom of a rip current or a } \\
\text { glaciofluvial channel }\end{array}$ \\
\hline$\overline{\text { RF6 }}$ & $\begin{array}{l}\text { Planar, dipping, parallel and continuous reflections becoming horizon- } \\
\text { tal or slightly concave at the bottom. The apparent dip angles of the } \\
\text { dipping reflections vary between } 12-23^{\circ} \text { towards the north. The low- } \\
\text { er boundary of the radar facies is downlapping at the southern part and } \\
\text { onlapping at the northern part. The upper boundary is erosionally trun- } \\
\text { cated by RS5 }\end{array}$ & $\begin{array}{l}\text { Rip current or glaciofluvial fan sedi- } \\
\text { ments }\end{array}$ \\
\hline$\overline{\mathrm{RS} 5}$ & Wavy, continuous reflection with an apparent dip towards the south & $\begin{array}{l}\text { Wave-cut surface or original surface of } \\
\text { RF4 }\end{array}$ \\
\hline$\overline{R F 7}$ & $\begin{array}{l}\text { Planar to slightly dipping at the upper part, subparallel to parallel con- } \\
\text { tinuous reflections. The upper part of the radar facies is masked by the } \\
\text { reflections and shadow reflections from the ground water and ground } \\
\text { surfaces. The lower boundary is concordant at the northern part and on- } \\
\text { lapping at the southern part }\end{array}$ & $\begin{array}{l}\text { Littoral reworking or hole fill sedimenta- } \\
\text { tion in the littoral stage. }\end{array}$ \\
\hline
\end{tabular}

\begin{tabular}{l|l|l}
\hline \multicolumn{2}{l}{ Figure 5 } & \multicolumn{2}{l}{} \\
\hline RF8 & $\begin{array}{l}\text { Complex series of wavy, oblique and discontinuous reflections with an } \\
\text { erosional upper boundary to RS5 }\end{array}$ & $\begin{array}{l}\text { Glacial diamicton ie. till. The origin of } \\
\text { the till is probably glaciotectonic }\end{array}$ \\
\hline RS6 & Wavy and slightly convex, continuous reflection & Erosional bottom of a proglacial channel \\
\hline RF9 & $\begin{array}{l}\text { Planar to mildly convex, parallel to subparallel, continuous reflections } \\
\text { with concordant and onlapping lower boundary to RS6 and erosional } \\
\text { upper boundary to RS7 }\end{array}$ & Proglacial channel fill \\
\hline RS7 & $\begin{array}{l}\text { Eastwards dipping at the western part and horizontal towards the east, } \\
\text { continuous reflection }\end{array}$ & $\begin{array}{l}\text { Erosional bottom of a rip current or a } \\
\text { glaciofluvial channel }\end{array}$ \\
\hline RF10 & $\begin{array}{l}\text { Planar to slightly curved, dipping, parallel to subparallel, continuous re- } \\
\text { flections with toplapping lower boundary to RS 7. The apparent dip an- } \\
\text { gles vary between 12-22 }\end{array}$ & $\begin{array}{l}\text { Rip current or glaciofluvial fan sedi- } \\
\text { ments }\end{array}$ \\
\hline
\end{tabular}




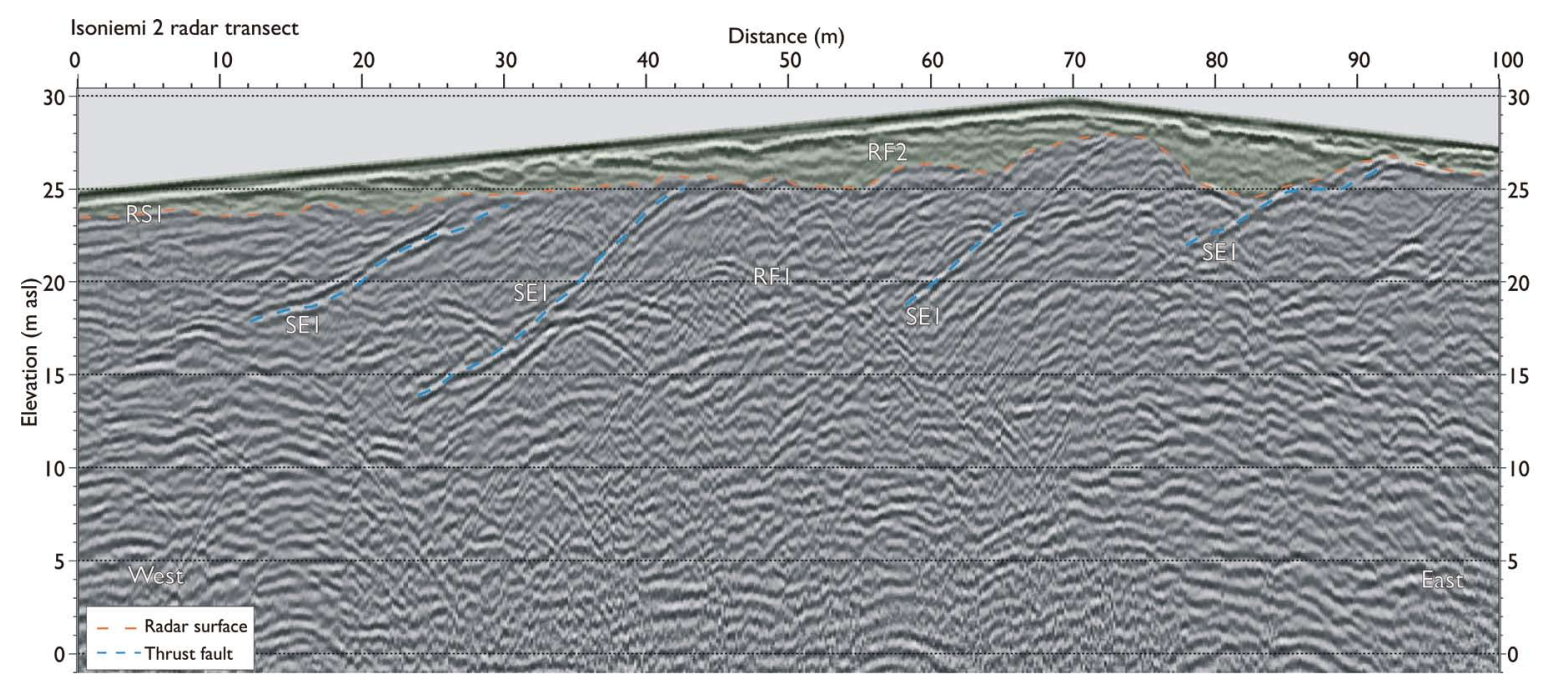

Fig. 3. Isoniemi 2 radar transect showing radar facies RFI (glaciotectonically deformed glaciofluvial deposit) and RF2 (littorally reworked sediments) separated by radar surface RSI (wave-cut surface). Reflections from secondary elements SEI are interpreted to represent glaciotectonic thrust faults. The results of radar stratigraphy and geological interpretation are given in Table 2 and discussed in the text.

\section{Interpretation}

\section{I Glaciotectonic and glacial deposits}

Radar facies RF1 in the Isoniemi 2 section (Fig. 3) show a complex radar reflection pattern with dipping radar reflections (secondary element SE1) cross-cutting the original strata. Radar facies RF4 in the Isoniemi 8 section (Fig. 4) also shows a similar reflection pattern, but no indication of SE1 was observed. RF1 is interpreted to represent glaciotectonically deformed glaciofluvial deposit, and the secondary element SE1 is interpreted to represent glaciotectonic thrust faults. The radar reflection patterns are similar to the ones showed by Jakobsen \& Overgaard (2002) and Bakker (2004) and the interpretations were confirmed with section logging in the Isoniemenkangas area (Fig. 2; Pasanen \& Lunkka, 2008). RF4 is interpreted to represent the same sedimentological facies even though its stratigraphical position above till was not seen in the sections in the Isoniemenkangas area. The interpretation is based on the reflection configuration and complex lower boundary (RS2) which is interpreted as glaciotectonically deformed. The bore- hole $\log$ in Figure 4 penetrating through RF4 is $20 \mathrm{~m}$ offset from the transect, but it gives an indication of the sediment type of RF4 (medium grained sand) and also RF3 (till).

RF3 in Figure 4 and RF8 in Figure 5 are interpreted to represent the same sedimentological facies. Radar transects Isoniemi 8 in Figure 4 and Isoniemi 7 in Figure 5 cross each other in almost right angles. When using 2D radar sections, the reflection patterns change with the transect direction and therefore, RF4 and RF8 are showing slightly different reflection patterns. RF4 and RF8 are interpreted to represent glacial diamicton, i.e., till. The interpretation was confirmed with several slightly offset borehole logs in the Kellonkangas area. The genesis of the till cannot be confirmed, but the section logs on the proximal side (Pasanen \& Lunkka, 2008) and the complex radar surface RS2 suggests a glaciotectonic nature. Also high amplitude, convex reflections at elevation $-1 \mathrm{~m}$ asl at the distance $275-300 \mathrm{~m}$ and at elevation $1 \mathrm{~m}$ asl at the distance 340-370 m (Fig. 4) suggests that there are lenses of probably stratified sediments, possibly sand, within the till. 


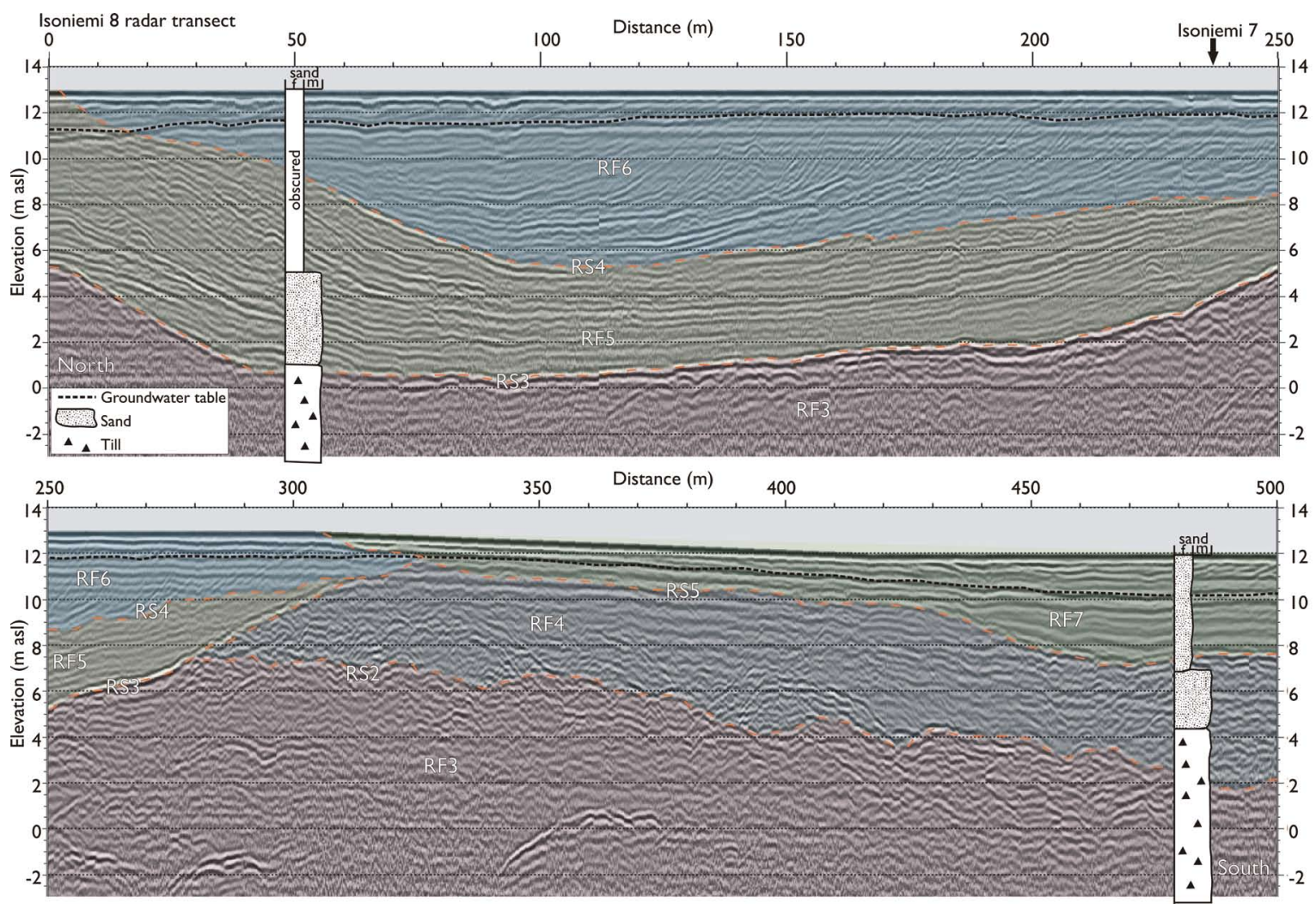

Fig. 4. Isoniemi 8 radar transect showing radar facies RF3 (till) overlain by radar surface RS2 (possible deformational boundary) and RS3 (erosional bottom of a proglacial channel). RF4 is interpreted to represent glaciotectonically deformed glaciofluvial deposit and RF5 as proglacial channel fill deposit. RF4 is overlain by RS5 (wave-cut surface or original surface of RF4) and RF5 by RS4 (erosional bottom of a rip current or a glaciofluvial channel). Above these radar surfaces RF6 (rip current or glaciofluvial fan sediments) and RF7 (littoral reworking or hole fill sedimentation in the littoral stage) were observed. Slightly offset borehole logs and location where radar transect Isoniemi 7 (Fig. 5) crosses the transect are indicated. The results of radar stratigraphy and geological interpretation are given in Table 2 and discussed in the text. See also legend in Figure 3.

\subsection{Glaciofluvial deposits}

Radar surfaces RS3 (Fig. 4) and RS6 (Fig. 5) are interpreted to show the same radar surface. The concave reflection, cutting RF3 and RF4, in Figure 4 and wavy reflection, cutting RF8, in Figure 5 is interpreted to represent an erosional bottom of a channel. Concave reflections of RF5 (Fig. 4) and planar to mildly convex reflections of RF9 (Fig. 5) are also interpreted to represent the same sandy channel fill sediments. The grain size of the sediments was confirmed with borehole data. Radar transect Isoniemi 8
(Fig. 4) is showing a transverse section of the channel, whereas radar transect Isoniemi 7 (Fig. 5) is showing the longitudinal section. The concave reflections of RF5 suggest a fast deposition with waning stream velocities suggesting that the channel was getting narrower by the deposited sediments. In the longitudinal section (Fig. 5), the reflections are mainly concordant to RS6, but at the eastern side of the topographic high of RS6 between 50-95 m, the lower boundary is onlapping. The onlapping is thought to be caused by the obstacle lee side sedimentation of the fast flowing water. The vast dimensions of the channel (width 


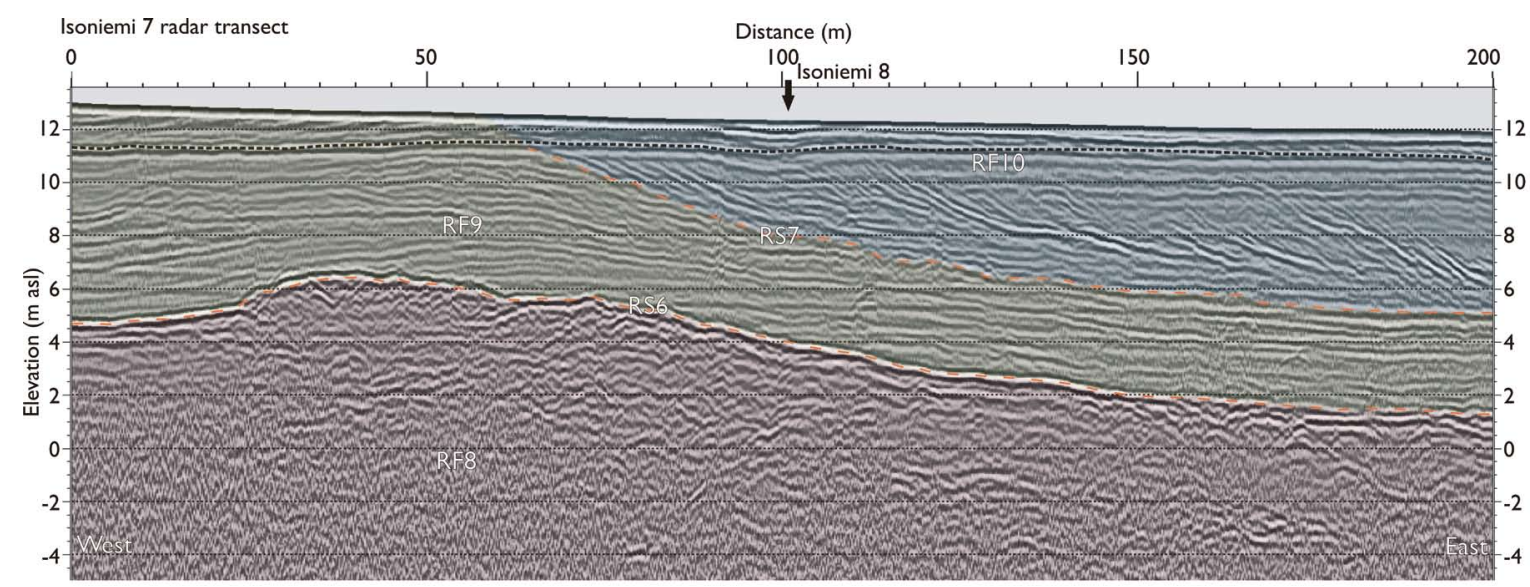

Fig. 5. Isoniemi 7 radar transect showing radar facies RF8 (till), RF9 (proglacial channel fill) and RFI0 (rip current or glaciofluvial fan sediments) separated by radar surfaces RS6 (erosional bottom of a proglacial channel) and RS7 (erosional bottom of a rip current or a glaciofluvial channel). Location of the crossing of the radar transect Isonie$\mathrm{mi} 8$ is indicated. The results of radar stratigraphy and geological interpretation are given in Table 2 and discussed in the text. Legend for the elements in the figure can be found in Figures 3 and 4.

$>300 \mathrm{~m}$ ) and the concave infilling and large scale lee side sedimentation suggests cutting and infilling in proglacial position with high, quickly waning stream velocity. The depth of the water in front of the ice margin (assumed to be more than $200 \mathrm{~m}$ ) is thought to be the reason for the quick waning in stream velocity. The low velocity infilling of the channel can be ruled out because of the concordant reflection ending at the lower boundary and concave reflections of RF5. The upper part of RF9 between 0-55 m shows westward dipping reflections, partly masked by reflections and shadow reflections from the ground surface and ground water level. The radar surface below these reflections could not be determined. Therefore, it cannot be stated whether these reflections belong to glaciofluvial deposits or if they represent, e.g., littoral or aeolian deposits.

\subsection{Littoral deposits}

The radar surface RS4 (Fig. 4) shows a concave reflection which is cutting RF3, RF4 and RF5, whereas RS7 (Fig. 5) is cutting RF9 and they are interpreted to represent the same radar surface. The geolog- ical interpretation for the combined radar surface is an erosional bottom of a channel. RF6 (Fig. 4) shows a reflection pattern with an apparent dip towards the north. RF10 (Fig. 5) also shows a dipping reflection configuration, but the apparent dip direction is towards the east. RF6 and RF10 are interpreted to represent the same sedimentological facies, where the 'true' dip direction of the clinoforms is estimated to be approximately towards the northeast. The radar sections Isoniemi 8 (Fig. 4) and Isoniemi 7 (Fig. 5) are probably cutting the channel diagonally. RF6 accompanied by RS4 (Fig. 4) may represent the reactivation of the glaciofluvial stream and proglacial fandelta sedimentation in a channel where dipping reflections represent foresets. The concordant reflection ending at the lower boundary at the south and onlapping reflection ending at the north may also suggest a bend in a channel, and the northward dipping reflections can be interpreted as bedding planes of a lateral bar. RF10 (Fig. 5), however, shows that the radar facies is not laterally continuous towards the west and it ends at the distance of $60 \mathrm{~m}$ in Figure 5. The dipping reflection pattern in RF6 and RF10 most probably suggests unidirectional water flow towards the 
northeast. Therefore, it is thought that radar facies RF5 and RF10 and radar surfaces RS4 and RS7 probably represent erosion and subsequent deltaic deposition possibly by rip currents (e.g. MacMahan et al., 2006). The depth of the observed modern rip channels are usually low (<2 m, MacMahan et al., 2006), whereas the depth of the channel in Figure 5 is at least $5 \mathrm{~m}$. Therefore, glaciofluvial erosion and deposition and subsequent erosion of the top of the facies, causing the end of the channel, can not be ruled out. However, no evidence of erosion at the top of the RF 6 and RF10 can be seen.

Radar surface RS1 (Fig. 3) erosionally truncates reflections at the upper boundary of RF1. RF2 shows planar reflections which are onlapping at the lower boundary. They are interpreted to represent littoral reworking of the earlier sediments above the wavecut surface (RS1). The interpretation is confirmed with section logging (Pasanen \& Lunkka, 2008). RF7 (Fig. 4) also shows a slightly similar reflection pattern. The borehole data, however, show that the sediment consists of fine-grained sand. This suggests that the sediment was removed from a higher elevation when the area was emerging from the Baltic Sea because of the glacioisostatic uplift, and the mass movements infilled the hollows at the lower elevation. Therefore, RS5 probably represents the original surface of RF4 rather than a wave-cut surface.

In the upper part of each radar transect (Figs. 3-5), a dipping reflection configuration can be seen. The reflections are partly masked by reflections and shadow reflections from the ground surface and ground water level, and no radar surfaces below them could be identified. It is thought that they may represent littoral or aeolian redeposition.

\subsection{Lateral distribution of the radar facies and surfaces}

The radar facies and radar surfaces are not distributed evenly in the study area. The glaciotectonic radar facies (RF1 and RF4) can be seen throughout the study area. The deformed glaciofluvial sediment is the thickest at the proximal side in the Isoniemenkan- gas area (Fig. 2) and it becomes thinner towards the distal side.

The till radar facies (RF3 and RF8) could not be identified in the Isoniemenkangas area. However, deformation till was seen in section logs (Pasanen $\&$ Lunkka, 2008) on the proximal side of the area. The GPR survey shows that the till bed is continuous at the distal side of the area, whereas at the proximal side only patches of till can be seen in the sections. The top 5-10 $\mathrm{m}$ of the sediment were removed in the central part of the study area between Isoniemenkangas and Annankangas (Fig. 2) and no transition from patchy till to continuous till bed could be identified.

The proglacial channels and channel fills (RS3, RS6, RF5 and RF9) were identified on the distal side of the area in Kellonkangas (Fig. 2). Another channel was identified $1.1 \mathrm{~km}$ to the south of the channel in Kellonkangas (Figs. 4 and 5) in the Soidinkangas area. Also another separate possible rip current channel and channel fill was identified $650 \mathrm{~m}$ south of the channel in Kellonkangas area in the Annanmäki area. The littoral radar facies (RF2 and RF4) was identified throughout the area.

\section{Discussion}

The till radar facies (RF3 and RF8) can be correlated with the diamicton facies of Pasanen \& Lunkka (2008). As mentioned above, even large till patches seen in the section logs next to the radar transect could not be identified in the radar section on the proximal side of the area. However, on the distal side the till radar facies is identified using borehole data. In Pasanen \& Lunkka (2008), an extensive exposure of diamicton was observed in a small pit and within folds on the proximal side of the area. This, alongside the observation of the probably glaciotectonised upper boundary of the till (RS2, Fig. 4), suggests that the till bed was laid down prior to or during the glaciotectonic deformation on top of the earlier deposited glaciofluvial sediment. However, Pasanen \& Lunkka (2008) identified two distinct shear stress directions on the proximal side of the study area, but the relative age of the events could not be determined. They 
also suggested that the deformation was caused by one glacier advance-retreat cycle, where the first deformation event occurred during the advance and latter one occurred during the retreat of the glacier. This suggests that the till bed was laid down by the advancing glacier causing also the deformation of the sediments below.

The glaciotectonic radar facies (RF1 and RF4) can be correlated with the deformed sand and gravel facies of Pasanen \& Lunkka (2008). The radar reflection pattern and section logs at the Runteli Ridge show a brittle to plastic glaciotectonic deformation. The 'true' dip angles of the secondary elements SE1, interpreted to represent glaciotectonic thrust faults, can not be determined and correlated with the shear stress directions presented in Pasanen \& Lunkka (2008). However, the deformation structures showing a northwest orientation becomes more abundant towards the proximal side of the area and it is thought to be the latest shear stress direction (Pasanen \& Lunkka, 2008). The thrust faults were most probably formed in this stage of the glaciotectonic deformation during the initial deglaciation ca. 10000 years ago. Also this latter stage of the deformation is thought to have caused the till bed to break into the small patches at the proximal side of the area.

The geomorphology of the Runteli Ridge is thought to have formed during the last deformation stage by shear stress applied from the northwest. The ridge shows a steep proximal slope which may represent an ice-contact slope, whereas the distal slope is gentle. The internal structures of the sediment and the geomorphology suggest that the genesis and the form of the Runteli Ridge owes to ice push, which is thought to have occurred at the same time the icecontact slope and the thrust faults were formed. Anyhow, no evidence of concurrent glaciofluvial sedimentation was observed. However, the initial deposition of the glaciofluvial sediment is most probably prior to the deformation events and the deposition of the till. The large scale proglacial channels and channel fills (RF5 and RF9) on the distal side of the study area back up this interpretation. The channels are thought to have formed during the retreat of the glacier prior to the formation of the Runteli Ridge. The proglacial channels are not seen in the radar sections or in the section logs on the proximal side of the area, which suggests that the area was still covered with ice at the time the proglacial channels were formed. The channels are cutting the till radar facies (RF3 and RF8) which implies that the till was deposited prior to the proglacial sedimentation and the last stage of the deformation.

The interpretation of the radar facies RF6 and RF10 (including radar surfaces RS4 and RS6) is problematic. The facies was not identified in the section logs (Pasanen \& Lunkka, 2008). The dipping radar reflections may owe their genesis to the proglacial glaciofluvial or rip current erosion and sedimentation. In the case of the proglacial glaciofluvial erosion and sedimentation, the relative age of the event is thought to be right after the deposition of the proglacial channel and channel fill radar facies (RF5 and RF9). In the case of the rip currents, the event is thought to have happened in the littoral position when the area was emerging from the sea because of the glacioisostatic uplift. The deep channel $(<5 \mathrm{~m}$, Figs. 4 and 5$)$ backs up the glaciofluvial interpretation, but the laterally discontinuous radar facies in Figure 5 suggests a rip current interpretation. Also the position of the radar transect Isoniemi 7 (Figs. 2 and 4) at the southern edge of the proglacial channel makes the interpretation difficult, and the depositional environment of the radar facies can not be stated unequivocally. Anyhow, erosion and deposition by rip currents are thought to be the most probable interpretation. It is thought that the open sea continued towards the east at least for a few kilometres when the area emerged from the sea.

The radar surface interpreted to represent wavecut surface (RS1) and radar facies showing littoral reworking of the earlier sediments (RF2) was correlated with the sand and pebble gravel facies of Pasanen $\&$ Lunkka (2008). The reworking occurred when the area emerged from the sea because of the glacioisostatic uplift during the Holocene. These deposits contain molluscs in places and their thickness can reach several metres. The infilling of the hollows (Fig. 4, 
RF7) was not seen in the section logs, but the fine sand sediment seen in the boreholes and onlapping lower boundary of the radar facies supports the interpretation.

\section{Conclusions}

GPR data interpreted with the radar stratigraphy technique can yield a substantial enhancement in the interpretation of the depositional environments in the coarse grained sediments compared to section logging and borehole data. This study expands the earlier sedimentological study in the area by Pasanen \& Lunkka (2008). GPR provided the possibility to study the lateral continuity of the deposits, and new facies were found that were not previously observed in the sedimentological study by Pasanen \& Lunkka (2008). The sequence of events, presented below, is based on the results of the sedimentological and GPR studies.

1. The deposition of the glaciofluvial fan-delta sediments occurred.

2. The advancement of the ice-sheet to the area probably from the west or the southwest occurred, and there was a deposition of the till and the deformation of the earlier glaciofluvial fan-delta sediments.

3. The retreat of the ice-sheet from the area occurred and was followed by the cutting and infilling of the proglacial glaciofluvial channels in the deep water (>200 m).

4. The formation of the Runteli ridge occurred by pushing of the readvancing or fluctuating ice-sheet from the northwest. The proglacial glaciotectonic deformation caused the breaking of the till bed into till patches and the formation of the thrust faults in the proximal side of the study area. This event is thought to have occurred during the initial deglaciation $c a .10000$ years ago.

5. Glacioisostatic uplift raised the area to the littoral position causing the rip current erosion and sedimentation in the distal side of the study area. The wave and sea-ice action reworked the earlier sediments causing horizontally deposited sediments above the wave-cut surface. Mass movements also occurred dispersing the sediments to the lower level, where they infilled the hollows in the sea floor.

\section{Acknowledgements}

This study was funded by the Finnish Academy Research Grant 210909, University of Oulu Thule Institute's PACE -project and the National Researcher School in Geology. Professor Juha Pekka Lunkka is thanked for discussion and comments on the manuscript, M.Sc. Tiina Eskola for assisting in the field, and Phil.Lic. Hannu Vehkaperä for providing the borehole data. The author would like to thank Professor James S. Aber, Dr. Marcel A.J. Bakker and Dr. Pertti Sarala for their constructive reviews of this article.

\section{References}

Annan, A.P. \& Davis, J.L., 1976. Impulse radar sounding in permafrost. Radio Science 11, 383-394.

Bakker, M.A.J., 2004. The internal structure of Pleistocene push moraines. A multidisciplinary approach with emphasis on ground-penetrating radar. Unpublished $\mathrm{PhD}$ thesis. TNO Built Environment and Geosciences, Geological Survey of Netherlands, $180 \mathrm{p}$.

Bakker, M.A.J. \& Van der Meer, J.J.M., 2003. Structure of a Pleistocene push moraine revealed by GPR: the eastern Veluwe Ridge, The Netherlands. Geological Society, London, Special Publications 211, 143-151.

Bargel, T., Huhta, P., Johansson, P., Lagerbäck, R., Mäkinen, K., Nenonen, K., Olsen, L., Rokoengen, K., Svedlund, J.O., Väänänen, T. \& Wahlroos, J.E., 1999. Maps of Quaternary geology in central Fennoscandia, sheet 3: ice-flow indicators, scale 1:1000 000, and Quaternary stratigraphy, scale 1:2000 000 .

Beres, M., Green, A., Huggenberger, P. \& Horstmeyer, H., 1995. Mapping the Architecture of Glaciofluvial Sediments with 3-Dimensional Georadar. Geology 23, 10871090.

Beres, M., Huggenberger, P., Green, A.G. \& Horstmeyer, H., 1999. Using two- and three-dimensional georadar methods to characterize glaciofluvial architecture. Sedimentary Geology 129, 1-24.

Busby, J.P. \& Merritt, J.W., 1999. Quaternary deformation mapping with ground penetrating radar. Journal of Applied Geophysics 41, 75-91.

Daniels, D.J., Gunton, D.J. \& Scott, H.F., 1988. Introduction to subsurface radar. IEE Proceedings 135, 128-320.

Davis, J.L. \& Annan, A.P., 1989. Ground-Penetrating Radar for High-Resolution Mapping of Soil and Rock Stratigraphy. Geophysical Prospecting 37, 531-551. 
Eronen, M., Forsström, L., Holappa, K., Jungner, H. \& Roman, S., 1995. Radiohiiliajoitus Oulun Hangaskankaan sinisimpukkaesiintymästä. Geologi 47, 47-52.

Gawthorpe, R.L., Collier, R.E.L., Alexander, J., Bridge, J.S. \& Leeder, M.R., 1993. Ground penetrating radar: application to sandbody geometry and heterogeneity studies. Geological Society, London, Special Publications 73, 421-432.

Gibbard, P.L., 1979. Late Pleistocene Stratigraphy of the Area around Muhos, North Finland. Annales Academiae Scientiarum Fennicae AIII 129, 1-38.

Helle, R. \& Ylinen, M., 1965. Hangaskankaasta KajaaninRokuan harjujaksossa. Yritys siitepölyanalyysin ja radiohiiliajoituksen avulla selvittää harjun rakennetta. Terra $77,104-111$.

Helmens, K.F., Johansson, P.W., Räsänen, M.E., Alexanderson, H. \& Eskola, K.O., 2007. Ice-free intervals continuing into marine isotope stage 3 at Sokli in the central area of the Fennoscandian glaciations. Bulletin of the Geological Society of Finland 79, 17-39.

Hirvas, H., 1991. Pleistocene stratigraphy of Finnish Lapland. Geological Survey of Finland, Bulletin 354, 1-123.

Hirvas, H. \& Nenonen, K., 1987. The till stratigraphy of Finland. Inqua till symposium, Finland 1985. Geological survey of Finland, Special paper 3, 49-63.

Hänninen, P., 1991. Maatutkaluotaus maaperägeologisissa tutkimuksissa. Geologian tutkimuskeskus, Tutkimusraportti $103,1-37$.

Jakobsen, P.R. \& Overgaard, T., 2002. Georadar facies and glaciotectonic structures in ice marginal deposits, northwest Zealand, Denmark. Quaternary Science Reviews 21, 917-927.

Johansson, P. \& Kujansuu, R. (eds.), 2005. Pohjois-Suomen maaperä: maaperäkarttojen 1:400 000 selitys. Summary: Quaternary deposits of Northern Finland - explanation to the maps of Quaternary deposits 1:400 000. Espoo. Geological Survey of Finland, 236 p.

Jol, H.M. \& Smith, D.G., 1991. Ground Penetrating Radar of Northern Lacustrine Deltas. Canadian Journal of Earth Sciences 28, 1939-1947.

Lønne, I. \& Lauritsen, T., 1996. The architecture of a modern push-moraine at Svalbard as inferred from groundpenetrating radar measurements. Arctic and Alpine Research 28, 488-495.

Lunkka, J.P., Johansson, P., Saarnisto, M. \& Sallasmaa, O., 2004. Glaciation of Finland. In: Ehlers, J. \& Gibbard, P.L. (eds.) Quaternary Glaciations - Extent and Chronology. Elsevier, Amsterdam, pp. 93-100.

MacMahan, J.H., Thornton, E.B. \& Reniers, J.H.M., 2006. Rip current review. Coastal Engineering 53, 191-208.

Mäkinen, J. \& Räsänen, M., 2003. Early Holocene regressive spit-platform and nearshore sedimentation on a glaciofluvial complex during the Yoldia Sea and the Ancylus Lake phases of the Baltic Basin, SW Finland. Sedimentary Geology 158, 25-56.

Neal, A., 2004. Ground-penetrating radar and its use in sed- imentology: principles, problems and progress. EarthScience Reviews 66, 261-330.

Neal, A., Richards, J. \& Pye, K., 2002. Sedimentology of coarse-clastic beach-ridge deposits, Essex, southeast England. Sedimentary Geology 162, 167-198.

Nenonen, K., 1995. Pleistocene stratigraphy and reference sections in southern and western Finland. Geological Survey of Finland, Kuopio. 205 p.

Overgaard, T. \& Jakobsen, P.R., 2001. Mapping of glaciotectonic deformation in an ice marginal environment with ground penetrating radar. Journal of Applied Geophysics 47, 191-197.

Pasanen, A. \& Lunkka, J.P., 2008. Glaciotectonic deformation of till-covered glaciofluvial deposits in Oulu region, Finland. Bulletin of the Geological Society of Finland 80, 89-103.

Pelpola, C.P. \& Hickin, E.J., 2004. Long-term bed load transport rate based on aerial-photo and ground penetrating radar surveys of fan-delta growth, Coast Mountains, British Columbia. Geomorphology 57, 169-181.

Roberts, M.C., Niller, H.-P. \& Helmstetter, N., 2003. Sedimentary architecture and radar facies of a fan delta, Cypress Creek, West Vancouver, British Columbia. Geological Society, London, Special Publications 211, 111-126.

Roksandic, M.M., 1978. Seismic facies analysis concepts. Geophysical Prospecting 26, 383-398.

Salonen, V., Kaakinen, A., Kultti, S., Miettinen, A., Eskola, K.O. \& Lunkka, J.P., 2007. Middle Weichselian glacial event in the central part of the Scandinavian Ice Sheet recorded in the Hitura pit, Ostrobothnia, Finland. Boreas $37,38-54$.

Sangree, J.B. \& Widmier, J.M., 1979. Interpretation of depositional facies from seismic data. Geophysics 44, 131-160.

Smith, D.G. \& Jol, H.M., 1992. Ground-Penetrating Radar Investigation of a Lake Bonneville Delta, Provo Level, Brigham-City, Utah. Geology 20, 1083-1086.

Smith, D.G. \& Jol, H.M., 1997. Radar structure of a Gilbert-type delta, Peyto Lake, Banff National Park, Canada. Sedimentary Geology 113, 195-209.

Sutinen, R., 1992. Glacial Deposits, their electrical properties and surveying by image interpretation and ground penetrating radar. Geological Survey of Finland, Bulletin 392, 1-123.

Tikkanen, M. \& Oksanen, J., 2002. Late Weichselian and Holocene shore displacement history of the Baltic Sea in Finland. Fennia 180.

van Dam, R.L. \& Schlager, W., 2000. Identifying causes of ground-penetrating radar refections using time-domain refectometry and sedimentological analyses. Sedimento$\operatorname{logy}$ 47, 435-449.

Vehkaperä, H., 1988. Maaperägeologiset tekijät maankäytön suunnittelussa. Esimerkkitapauksena HämeenjärviJäälinjärvi-alue Haukiputaan ja Kiimingin kunnissa. Unpublished Licentiate Study, University of Oulu, 90 p. 